\title{
Penetration of amoxycillin/clavulanic acid into bronchial mucosa with different dosing regimens
}

\author{
I M Gould, G Harvey, D Golder, T M S Reid, S J Watt, J A R Friend, J S Legge, \\ J G Douglas
}

\begin{abstract}
Background - The efficacy of an antibiotic is related to its concentration at the site of infection. Previous studies of the concentrations of amoxycillin and clavulanic acid (co-amoxiclav) in respiratory secretions or whole lung tissue have suffered from methodological problems. The concentration of amoxycillin and clavulanic acid was determined in bronchial mucosal biopsy samples obtained at bronchoscopy following five different dosing regimens.

Methods - Bronchial biopsy and serum samples were obtained from 50 patients undergoing diagnostic bronchoscopy. Ten patients each received $375 \mathrm{mg}, 625 \mathrm{mg}$, $750 \mathrm{mg}$, and $3.25 \mathrm{~g}$ oral, and $1.2 \mathrm{~g}$ intravenous co-amoxiclav 1-3 hours before bronchoscopy. The concentrations of clavulanic acid and amoxycillin were determined by high performance liquid chromatography using a microbore column, solid phase extraction, and preconcentration to improve sensitivity tenfold over previous methods.

Results - Concentrations of both clavulanic acid and amoxycillin in bronchial mucosa were dose related and were well above the $\mathrm{MIC}_{90}$ of co-amoxiclav for the common bacterial respiratory pathogens including Haemophilus influenzae, Micrococcus catarrhalis and Streptococcus pneumoniae for all dosing regimens. Mean mucosal levels were $200 \%$ and $118 \%$ of the corresponding serum levels for amoxycillin and clavulanic acid respectively.

Conclusions - Amoxycillin and clavulanic acid are concentrated in bronchial mucosa and, even at the lowest dose of $375 \mathrm{mg}$ orally, are likely to produce tissue levels in the lung sufficient to inhibit all the common community acquired respiratory pathogens.
\end{abstract}

(Thorax 1994;49:999-1001)

Several studies have attempted to assess the concentrations of amoxycillin and clavulanic acid in respiratory secretions ${ }^{1-5}$ and whole lung tissue. ${ }^{6}$ Antibiotic concentrations in sputum and bronchial mucus vary greatly because of difficulty in sampling, drug instability, and contamination by blood and saliva. ${ }^{7-8}$ Bronchial washings also suffer from the same problems and are further compounded by the dilutional effect of lavage. Lung tissue obtained at thoracotomy is non-homogenous and so represents an average of concentrations found in different tissues. The concentration of antibiotic in bronchial mucosa provides a reliable guide to bronchial penetration ${ }^{910}$ and may be a better predictor of clinical efficacy than the serum level ${ }^{11}$ for treatment of bronchitis and bronchopneumonia. Although one study has investigated the concentration of amoxycillin in bronchial mucosa, ${ }^{9}$ there have only been provisional reports on the bronchial mucosal levels of clavulanic acid. ${ }^{1213}$ We have assessed levels of amoxycillin and clavulanic acid in the bronchial mucosa following the administration of coamoxiclav by five different dosing regimens in patients undergoing diagnostic bronchoscopy.

\section{Methods}

The study was approved by the hospital ethical committee and informed consent was obtained. Patients were excluded if they were pregnant, suffering from severe cardiovascular or renal disease, hypersensitive to $\beta$-lactams, undergoing bronchoscopy for diagnosis of infection, or had received systemic antibacterial chemotherapy in the previous three days. Fifty patients, 10 for each dosing regimen, undergoing diagnostic bronchoscopy were enrolled. No patient had clinical signs of bronchial infection during the study. Patients received $375 \mathrm{mg}, 625 \mathrm{mg}, 750 \mathrm{mg}$, or $3.25 \mathrm{~g}$ oral coamoxyiclav or $1.2 \mathrm{~g}$ intravenously $1-3$ hours before bronchoscopy.

Fibreoptic bronchoscopy was performed under general anaesthetic and serum samples were obtained prior to mucosal biopsy. Two biopsy specimens were taken from secondary carinae in both lungs. Grossly blood contaminated biopsies were discarded. Specimens were transported to the laboratory on ice, weighed and buffered to $\mathrm{pH} 6$ in $200 \mu \mathrm{l} \mathrm{NaH} \mathrm{PO}_{4}$, and stored at $-70^{\circ} \mathrm{C}$ within 90 minutes of collection. Weighing the biopsy samples before storage avoided any risk of artificial concentration of the drug in the event of desiccation of the sample. Before assay mucosal samples were homogenised by ultrasonication on ice to prevent overheating during processing. A tapered microtip attached to the horn of an ultrasonicator (Branson Sonic Power, Danbury, Connecticut, USA) was used and each biopsy sample was subjected to 20-30 seconds of ultrasonication to give a uniform suspension ready for high performance liquid 
Table 1 Mean (SD) and coefficient of variation (CV) in serum and bronchial mucosal levels of amoxycillin following administration of co-amoxiclav

\begin{tabular}{|c|c|c|c|c|c|c|c|}
\hline \multirow{2}{*}{\multicolumn{2}{|c|}{$\begin{array}{l}\text { Dose of amoxycillin } \\
\text { (co-amoxiclav) }\end{array}$}} & \multicolumn{3}{|c|}{$\begin{array}{l}\text { Serum levels } \\
(\mathrm{mg} / \mathrm{l})\end{array}$} & \multicolumn{3}{|c|}{$\begin{array}{l}\text { Bronchial mucosa } \\
\text { levels (mg/kg) }\end{array}$} \\
\hline & & $\overline{M e a n}$ & $(S D)$ & $C V$ & Mean & $(S D)$ & $C V$ \\
\hline $\begin{array}{l}250 \mathrm{mg} \\
500 \mathrm{mg} \\
500 \mathrm{mg} \\
1 \mathrm{~g} \\
3 \mathrm{~g}\end{array}$ & $\begin{array}{l}(375 \mathrm{mg}) \\
(625 \mathrm{mg}) \\
(750 \mathrm{mg}) \\
(1.2 \mathrm{~g}) \\
(3.25 \mathrm{~g})\end{array}$ & $\begin{array}{r}2 \cdot 6 \\
5 \cdot 6 \\
5 \cdot 1 \\
8 \cdot 4 \\
10 \cdot 9\end{array}$ & $\begin{array}{l}(1.37) \\
(1.87) \\
(1.59) \\
(2.34) \\
(2.43)\end{array}$ & $\begin{array}{l}0.53 \\
0 \cdot 33 \\
0 \cdot 31 \\
0 \cdot 27 \\
0 \cdot 22\end{array}$ & $\begin{array}{r}4 \cdot 1 \\
10 \cdot 1 \\
7 \cdot 2 \\
20 \cdot 8 \\
23 \cdot 1\end{array}$ & $\begin{array}{l}(1.58) \\
(1 \cdot 75) \\
(2.58) \\
(5 \cdot 71) \\
(5 \cdot 1)\end{array}$ & $\begin{array}{l}0.38 \\
0.17 \\
0.35 \\
0.27 \\
0.22\end{array}$ \\
\hline
\end{tabular}

Table 2 Mean (SD) and coefficient of variation (CV) in serum and bronchial mucosal levels of clavulanic acid

\begin{tabular}{|c|c|c|c|c|c|c|c|}
\hline \multicolumn{2}{|c|}{$\begin{array}{l}\text { Dose of clavulanic } \\
\text { acid (co-amoxiclav) }\end{array}$} & \multicolumn{3}{|c|}{$\begin{array}{l}\text { Serum levels } \\
(\mathrm{mg} / \mathrm{l})\end{array}$} & \multicolumn{3}{|c|}{$\begin{array}{l}\text { Bronchial mucosa } \\
\text { levels (mg/kg) }\end{array}$} \\
\hline & & $\overline{M e a n}$ & $(S D)$ & $C V$ & $\overline{M e a n}$ & $(S D)$ & $C V$ \\
\hline $\begin{array}{l}125 \mathrm{mg} \\
125 \mathrm{mg} \\
250 \mathrm{mg} \\
200 \mathrm{mg} \\
250 \mathrm{mg}\end{array}$ & $\begin{array}{l}(375 \mathrm{mg}) \\
(625 \mathrm{mg}) \\
(750 \mathrm{mg}) \\
(1.2 \mathrm{~g}) \\
(3.25 \mathrm{~g})\end{array}$ & $\begin{array}{l}1 \cdot 4 \\
2 \cdot 3 \\
2 \cdot 3 \\
2 \cdot 7 \\
2 \cdot 9\end{array}$ & $\begin{array}{l}(0.82) \\
(0.85) \\
(1 \cdot 15) \\
(0.77) \\
(1.4)\end{array}$ & $\begin{array}{l}0.58 \\
0.37 \\
0.50 \\
0.28 \\
0.48\end{array}$ & $\begin{array}{l}1.9 \\
2 \cdot 4 \\
1.6 \\
3.6 \\
4 \cdot 1\end{array}$ & $\begin{array}{l}(0.72) \\
(0.94) \\
(0.47) \\
(1.35) \\
(1.65)\end{array}$ & $\begin{array}{l}0 \cdot 37 \\
0 \cdot 38 \\
0 \cdot 30 \\
0 \cdot 37 \\
0 \cdot 40\end{array}$ \\
\hline
\end{tabular}

chromatography with a microbore column, solid phase extraction, and preconcentration. ${ }^{14}$ Spiked standards were prepared in water from pure powder. Fresh antibiotic free biopsy tissue was ultrasonicated with buffer to produce a control biopsy suspension. Standards and biopsy suspension or serum were mixed 1:1 to give a range of known biopsy standards of 500 , $250,125,64,32,16$ and $8 \mu \mathrm{g} / \mathrm{kg}$ for clavulanic acid and 1000, 500, 250, 125, 64 and $32 \mu \mathrm{g} / \mathrm{kg}$ for amoxycillin. Blank standards were included. Serum standards were $4,2,1,0.5$ and $0.25 \mathrm{mg} /$ 1 for clavulanic acid and $8,4,2,1$ and $0.5 \mathrm{mg} /$ 1 for amoxycillin. The biopsy and serum standards were treated in the same way as the biopsy and serum samples. For clavulanic acid internal standard (Salicylamide) was added, derivatised with imidazole, and concentrated using a C18 Bond Elut cartridge as previously prescribed. Amoxycillin was assayed by HPLC. ${ }^{15}{ }^{16}$. Plots of the standards were used to obtain the values of the samples after HPLC analysis. Lower limits of the assay were $8 \mu \mathrm{g} / 1$ or $\mu \mathrm{g} / \mathrm{kg}$ for clavulanic acid and $32 \mu \mathrm{g} / \mathrm{l}$ or $\mu \mathrm{g} / \mathrm{kg}$ for amoxycillin. Samples were assayed in batches of 6-10 with standards stored under the same conditions. Within and between assay precision was $96-99 \%$.

\section{Results}

Mean mucosal biopsy weights were $1.69 \mathrm{mg}$, $1.4 \mathrm{mg}, 1.25 \mathrm{mg}, 1.79 \mathrm{mg}$, and $1.34 \mathrm{mg}$ for the five dosage groups respectively. All samples had detectable levels of amoxycillin and clavulanic acid in the mucosal biopsy and serum samples, with the exception of two patients on the $750 \mathrm{mg}$ dose of co-amoxiclav who had undetectable levels of clavulanic acid (tables 1 and 2). These patients had the lowest serum levels of clavulanic acid in their dosing group $(0.875$ and $0.91 \mathrm{mg} / \mathrm{l})$, although they both had high mucosal and serum levels (11.15 and $8.8 \mathrm{mg} / \mathrm{kg}$ ) of amoxycillin. The time of sampling after dosing was one hour and 1.75 hour respectively for these two patients. Forty one samples were taken 1-2 hours after the drug was administered and the remaining nine samples 2-3 hours after, so serum levels ap- proximate to peak levels. ${ }^{17}$ Percentage penetration into the bronchial mucosa was $200 \%$ for amoxycillin (range 158-248\%) with concentrations increasing with dose. Penetration for clavulanic acid was $118 \%$ (range $70-136 \%$ ) and again concentrations increased with dose, except for the $750 \mathrm{mg}$ oral dose where levels were lower than expected for no obvious reason.

\section{Discussion}

The concentrations of amoxycillin and clavulanic acid found in bronchial mucosa in this study are up to 20 times higher than in bronchial mucus and sputum. ${ }^{1-5}$ Higher concentrations of $\beta$-lactams occur in bronchial mucosa than in mucus ${ }^{18}$ and we have noticed a similar difference between bronchial mucus and mucosal levels for aztreonam (unpublished). The mucosal levels of amoxycillin are approximately double those where mean mucosal concentrations of amoxycillin were $75 \%$ of simultaneous serum levels. ${ }^{9}$ Preliminary results from a further study by the same group have shown similar levels to our own for both amoxycillin and clavulanic acid. ${ }^{13}$ The difference in results might be due to the use of a bioassay, ${ }^{9}$ different times between drug dosing and biopsy sampling, and different biopsy weights, suggesting different tissue site samples.

The mucosal amoxycillin levels are well above the $\mathrm{MIC}_{90}$ of all common $\beta$-lactamase negative respiratory pathogens, even at the $250 \mathrm{mg}$ dose of amoxycillin. Similarly, the mucosal concentrations of clavulanic acid, even at the $125 \mathrm{mg}$ dose, may be sufficient to maximally inhibit the $\beta$-lactamases of all the common community acquired respiratory pathogens although this remains to be proven. For $\beta$-lactamase positive organisms such as $\mathrm{Sta}$ phylococcus aureus, Haemophilus influenzae, and Micrococcus cattarhalis the MIC $_{90}$ for amoxycillin/clavulanic acid is easily achieved by the $375 \mathrm{mg}$ dose. This may be important as there is evidence that tissue levels several times greater than the in vitro MIC level are necessary for optimal antimicrobial activity at certain sites of 
infection. ${ }^{19}$ This degree of concentration in mucosa is similar to that seen with ciprofloxacin $^{20}$ and cefuroxime, but greater than that seen with other $\beta$-lactams. ${ }^{111182122}$

The tissue concentrations reported provide a valid basis for the use of co-amoxiclav in the treatment of pneumonia and bronchitis. Ideal dosing regimens may be designed when the duration of therapeutic tissue levels, post antibiotic effects, and the relevance of in vitro studies on $\beta$-lactamase inhibition and antibacterial activity to the in vivo situation are understood. It appears that, for $\beta$-lactams, good bronchial mucosal levels are easily achieved. Poor clinical response or relapse, reported in some patients infected with sensitive organisms, may be due to a reservoir of organisms in the bronchial secretions where therapeutic levels are not so easily attained.

The authors wish to thank Patricia Collins and SmithKline Beecham for all the help and financial support.

1 Kosmidis J. Pharmacokinetics of clavulanic acid combinations: an overview. Proceedings 4th Mediterranean Conbinations: an overview. Proceedings 4th Mediterranean Consuppl): $164-5$.

2 Gould IM. Legge JS, Reid TMS. Amoxycillin/clavulanic acid levels in lower respiratory secretions. $\mathcal{f}$ Antimicrob Chemother 1988;88-9.

3 Havard CWH, Fernando A, Brumfitt W, Hamilton-Miller JMT. A pilot study of "Augmentin" in lower respiratory tract infections: pharmacokinetic and clinical results. $\mathrm{Br}$ tract infections: pharmacokine

4 Maeson FPV, Davies BI, Baur C. Amoxycillin/clavulanate in acute purulent exacerbation of chronic bronchitis. $\mathcal{F}$ Antimicrob Chemother 1987;19:373-83.

5 Lovering AM, Pycock CJ, Harvey JE, Reeves DS. The pharmacokinetics and sputum penetration of ampicillin and amoxycillin following simultaneous IV administration. f Antimicrob Chemother 1990;25:385-92.

6 Cox AL, Meewis JM, Horton R. Penetration into lung tissue after intravenous administration of amoxycillin/clavulanic acid. $\mathcal{f}$ Antimicrob Chemother 1989;24(Suppl B):87-91.
7 Bergogne-Berezin E. Penetration of antibiotics into the respiratory tree. F Antimicrob Chemother 1981;8:171-4.

8 Pennington JE. Penetration of antibiotics into respiratory secretions. Rev Infect Dis 1981;3:67-73.

9 Honeybourne D, Andrews JM, Ashby JP, Lodwick R, Wise R. An evaluation of the penetration of ciprofloxacin and amoxycillin into the bronchial mucosa. Thorax 1988;43: 715-9.

10 Marlin GE, Nicholls AJ, Funnell GR, Bradbury. Penetration of cefaclor into bronchial mucosa. Thorax 1984;39:813-7.

11 Baldwin DR, Maxwell SRJ, Honeybourne D, Andrews JM, Ashby JP, Wise R. The penetration of cefpirome into the potential sites of pulmonary infection. $\mathcal{F}$ Antimicrob Chemother 1991;28:79-86.

12 Gould IM, Reid TMS, Golder D, Legge J, Douglas G, Friend J, et al. Penetration of amoxycillin/clavulanate (aug-
mentin) into bronchial mucosa with different dosing rementin) into bronchial mucosa with different dosing regimens. Proceedings of 7 th Mediteranean
Chemotherapy, Barcelona 1990, Abstract 689.

13 Honeybourne D, Baldwin DR, Wise R, Andrews JM. Comparative concentrations of cefuroxime, amoxycillin and clavulanic acid in bronchial mucosal biopsies following oral administration. 17th International Congress of Chemotherapy, Berlin 1991, Abstract 975.

14 Low AS, Taylor RB, Gould IM. Determination of clavulanic acid by a sensitive HPLC method. $\mathcal{F}$ Antimicrob Chemother 1989;24(Suppl B):83-6.

15 Beecham Pharmaceuticals Research Division. Augmentin: recommendations for the handling, storage and assay in human body fluids. Part 3. The HPLC assay of amoxycillin in body fluids. 1981:17-7.

16 White LO, Lovering AM and Bowyer H. HPLC in microbiology 2nd edn. Department of Microbiology, Southmead Hospital, Bristol. 1986:13.

17 Westphal JF, Deslandes A, Brogard JM, Carbon C. Reappraisal of amoxycillin absorption kinetics. $\mathcal{F}$ Antimicrob Chemother 1991;27:647-54.

18 Martin GE, Burgess KR, Burgoyne J, Funnel GR, Guinness MDG. Penetration of piperacillin into bronchial mucosa and sputum. Thorax 1981;36:774-80.

19 Tauber MG, Kunz S, Zak O, Sande MA. Influence of antibiotic dosing interval and duration of therapy on outcome in experimental pneumococcal meningitis in rabbits. Antimicrob Agents Chemother 1989;33:418-23.

20 Reid TMS, Gould IM, Golder D, Legge JS, Douglas JG, Friend JAR, et al. Respiratory tract penetration of ciproFriend JAR, et al. Respiratory tract penetration

21 Chadha D, Wise R, Baldwin DR, Andrews JM, Ashby JP, Honeybourne D. Cefepime concentrations in bronchial mucosa and serum following a single 2 gram intravenous dose. $\mathcal{F}$ Antimicrob Chemother 1990;25:959-63.

22 Baldwin DR, Andrews JM, Ashby JP, Wise R, Honeybourne $D$. Concentration of cefixime in bronchial mucosa and sputum after three oral multiple dose regimens. Thorax 1990;45:401-2. 